\title{
STUDI DEFORMASI GUNUNGAPI BATUR DENGAN METODE SURVEI GPS
}

\author{
Hasanuddin Z. Abidin 1), M. Hendrasto 2), H. Andreas 1), \\ D. Darmawan 1), M. A. Kusuma 1), M. Gamal 1), \\ O.K. Suganda 2), Iing Kusnadi 2), A.D. Wirakusumah 2)
}

1) Departemen Teknik Geodesi, Institut Teknologi Bandung J1. Ganesha 10, Bandung 40132, e-mail : hzabidin@indo.net.id

2) Direktorat Vulkanologi and Mitigasi Bencana Geologi, J1. Diponegoro 57, Bandung 40122

\begin{abstract}
ABSTRAK
Pemantauan aktivitas gunungapi dapat dilakukan dengan berbagai metode, dimana salah satunya adalah metode deformasi. Pada dasarnya metode ini diterapkan untuk memperoleh pola dan kecepatan deformasi dari tubuh gunungapi, baik dalam arah horisontal maupun vertikal, yang selanjutnya dapat digunakan untuk mengestimasi lokasi serta ukuran dari pusat tekanan penyebab deformasi. Metode deformasi dapat diimplementasikan menggunakan beragam sensor dan teknik, dimana satu diantaranya adalah adalah teknik yang menggunakan pengamatan terhadap satelit GPS (Global Positioning System). Makalah ini akan menjelaskan karakteristik deformasi gunung Batur yang diperoleh dari tiga survei GPS yang telah dilaksanakan pada 1999, 2001 dan 2002. Penjelasan akan didasarkan pada perpanjangan dan perpendekan baseline, serta lokasi pusat tekanan yang diperoleh dari proses estimasi. Makalah akan diakhiri dengan beberapa catatan penutup.
\end{abstract}

\section{PENDAHULUAN}

Ada beberapa metode pemantauan aktivitas gunung api yang telah diaplikasikan sekarang ini [5,9], yaitu antara lain metode seismik, metode deformasi, metode kimia gas, metode termal, dan metode penginderaan jauh (dengan menggunakan sistem video, citra satelit, dan sebagainya). Metode-metode ini akan melibatkan sistem peralatan/sensor tersendiri, dan disamping itu dapat diimplementasikan secara episodik maupun kontinyu. Metode yang paling banyak digunakan untuk pemantauan gunung api di Indonesia saat ini adalah metode seismik. Metode seismik yang menggunakan sensor seismometer ini pada dasarnya digunakan untuk mengevaluasi aktivitas yang terjadi di dalam gunung api. Disamping metode seismik, metode deformasi pun cukup banyak diaplikasikan dalam pemantauan gunung api dengan menggunakan berbagai macam sensor atau sistem, dan metode ini dianggap punya potensi yang sangat besar untuk berkontribusi dalam pemantauan aktivitas gunung api. Metode ini pada dasarnya ingin mendapatkan pola dan kecepatan dari deformasi permukaan gunung api, baik dalam arah horisontal maupun vertikal.

Pada prinsipnya deformasi dari tubuh gunungapi dapat berupa penaikan permukaan tanah (inflasi) ataupun penurunan permukaan tanah (deflasi). Deformasi yang berupa inflasi umumnya terjadi karena proses gerakan magma ke permukaan yang menekan permukaan tanah di atasnya. Dalam hal ini deformasi yang maksimal biasanya teramati tidak lama sebelum letusan gunungapi berlansung. Sedangkan deformasi berupa deflasi umumnya terjadi selama atau sesudah masa letusan. Pada saat itu tekanan magma di dalam tubuh gunungapi telah melemah. Pada saat itu permukaan tanah cenderung kembali ke posisinya semula. Gejala deformasi gunungapi akan menyebabkan pergeseran posisi suatu titik di tubuh gunungapi. Pergeseran posisi tersebut dapat terjadi baik dalam arah horisontal maupun vertikal. Menurut [10], nilai pergeseran ini bisa mencapai puluhan meter pada gunungapi silisik yang membentuk kubah lava. Pada 
gunungapi yang kantong magmanya masih jauh di bawah permukaan atau gerakan naiknya magma relatif lambat, deformasi yang teramati relatif kecil, kadang-kadang nilai strain nya lebih kecil dari $0.1 \mathrm{ppm} /$ tahun.

Pemantauan deformasi suatu gunungapi dapat dilakukan dengan menggunakan berbagai macam sensor atau sistem. Metode deformasi ini pada dasarnya ingin mendapatkan pola dan kecepatan dari gerakan tubuh gunungapi, baik dalam arah horisontal maupun vertikal. Menurut [4], data dan informasi deformasi permukaan ini dapat digunakan untuk mengungkapkan beberapa hal tentang karakteristik dari aktivitas magmatik gunungapi yang bersangkutan, seperti : perubahan dari fluks magma (untuk kantong magma yang bersifat tetap), serta lokasi, bentuk, dan perkembangan kantong magma baru yang terbentuk karena proses intrusi.

Pemantauan deformasi gunung api dengan metode deformasi umumnya dapat diklasifikasikan atas dua tipe, yaitu metode episodik dan metode kontinyu. Pada metode episodik, pemantauan dilakukan secara berkala dalam selang waktu tertentu. Metode deformasi episodik ini umumnya menggunakan data-data pengamatan terestris, seperti jarak (dari EDM, Electronic Distance Measurement), arah (dari theodolit), beda tinggi (dari sipat datar), dan perubahan gaya berat (dari pengukuran mikrogravitas); dan sekarang ini juga mulai menggunakan data pengamatan GPS [1] dan juga INSAR (Interferometric Synthetic Aperture Radar). Sedangkan pada metode deformasi kontinyu pemantauan dilakukan terus menerus secara otomatis. Metode deformasi kontinyu ini umumnya menggunakan sensor-sensor tiltmeter, extensiometer, dan dilatometer, yang hanya mengkarakterisir deformasi yang sifatnya relatif lokal. Patut ditekankan di sini bahwa GPS yang dikombinasikan dengan sistem telemetri/komunikasi data juga mulai banyak digunakan untuk memantau deformasi gunung api secara kontinyu. Untuk gunung-gunung api yang lebih aktif, sehubungan dengan adanya tuntutan ketersediaan informasi deformasi dalam waktu yang relatif cepat, maka pemantauan secara kontinyu dengan GPS akan lebih efektif dibandingkan dengan penggunaan metode survai GPS.

Makalah ini akan menjelaskan penggunaan metode survei GPS secara periodik untuk studi deformasi gunung Batur. Karakteristik deformasi G. Batur yang diperoleh dari tiga kali survei GPS dan yang telah dilaksanakan pada tahun 1999, 2001 dan 2002 akan coba dijelaskan dan didiskusikan.

\section{GUNUNG BATUR}

Gunungapi Batur terletak dalam kaldera Batur, yang berada di bagian timur-laut pulau Bali, sekitar $70 \mathrm{~km}$ di utara Denpasar. Kaldera Batur pada dasarnya terdiri dari dua kaldera. Kaldera terluar berbentuk ellips berukuran sekitar $13.8 \mathrm{~km} \mathrm{x} 10 \mathrm{~km}$, dan kaldera sebelah dalam berbentuk lingkaran dengan jejari sekitar $7.5 \mathrm{~km}[2,3,11]$, seperti yang diilustrasikan pada Gambar 1 berikut.

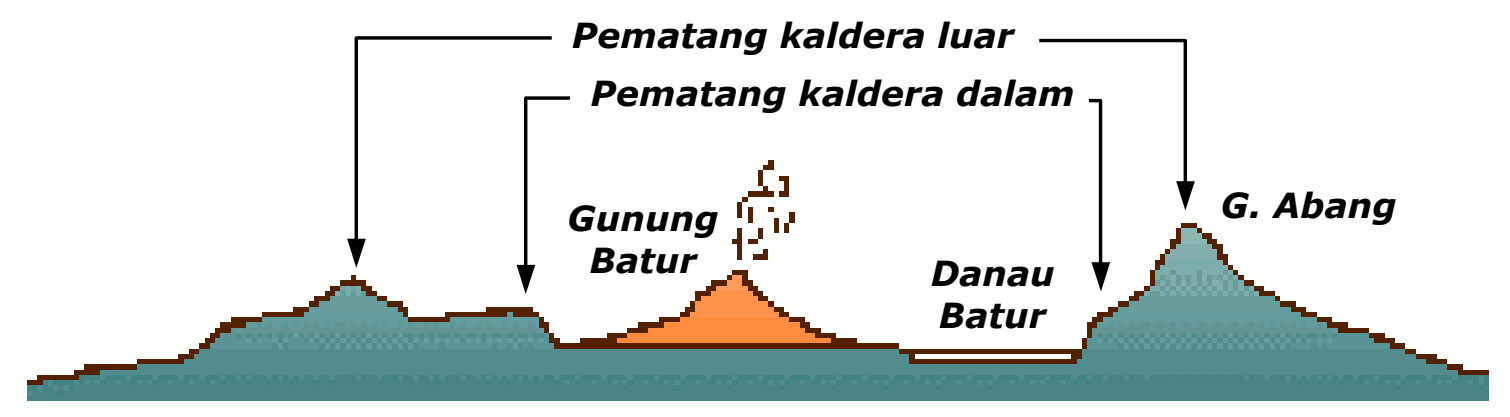

Gambar 1. Penampang kaldera batur, diadaptasi dari [12]. 
Pematang (tebing) kaldera mempunyai ketinggian antara $1267 \mathrm{~m}$ sampai $2152 \mathrm{~m}$ (puncak G. Abang). G. Batur sendiri yang terletak di tengah kaldera berketinggian sekitar $1717 \mathrm{~m}$ di atas muka laut dan sekitar $686 \mathrm{~m}$ di atas muka danau Batur yang juga terletak di dalam kaldera. Sedangkan danau Batur yang berbentuk bulan sabit, menutupi dasar kaldera sebelah timur dan tenggara, dengan panjang sekitar $7.5 \mathrm{~km}$, lebar maksimum sekitar $2.5 \mathrm{~km}$ dan sekeliling sekitar $22 \mathrm{~km}$. Gambaran fisik G. Batur dan panorama sekitarnya ditunjukkan pada Gambar 1.

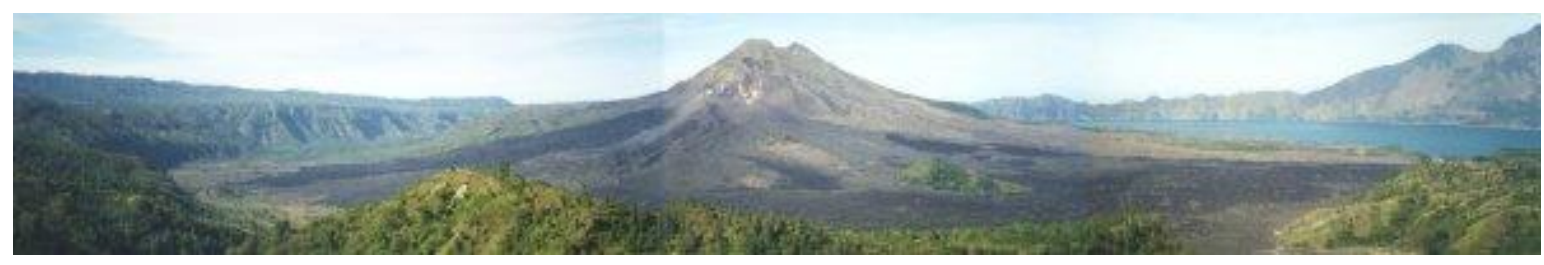

Gambar 1. Gunung Batur dan panorama sekitarnya [12].

Gunung Batur setidaknya telah meletus sebanyak 24 kali sejak 1800's, seperti ditunjukkan pada Tabel 1, dan tipe letusannya umumnya adalah Strombolian dengan aliran lava.
Tabel 1. Tahun letusan G. Batur [2,3]

1804, 1821, 1849, 1854, 1888, 1897, 1902, 1904, 1905, 1921, 1922, 1923, 1924, 1925, 1926, 1963, 1965, 1966, 1968, 1970, 1971, 1974, 1994, 1995

\section{SURVEI GPS DI GUNUNG BATUR}

Survei GPS untuk studi deformasi G. Batur telah dilaksanakan tiga kali, yaitu masingmasing pada tahun 1999, 2001 dan 2002, seperti yang ditunjukkan pada Tabel 2 disamping.

Tabel 2. Waktu pelaksanaan survei

Jaring GPS yang disurvei terdiri atas 12 titik seperti yang ditunjukkan pada Gambar 2 berikut. Titik DB01 yang berada di halaman Hotel \& Restoran Gunawan di Kintamani digunakan sebagai titik referensi, dan dalam analisa defor-masi dianggap sebagai titik stabil yang tidak mengalami deformasi. Dalam hal ini titik-titik DB08 dan LB07 adalah dua titik baru yang diamati hanya sejak survei GPS ketiga.

Survei GPS dilaksanakan oleh tim dari Jurusan Teknik Geodesi ITB dan Direktorat Vulkanologi dan Mitigasi Bencana Geologi dengan menggunakan receiver GPS tipe geodetik dua-frekuensi. Pada survei pertama dan kedua digunakan tiga receiver Ashtech Z-XII3 dan dua

\begin{tabular}{|c|c|}
\cline { 2 - 2 } \multicolumn{1}{c|}{} & Survei GPS \\
\hline Survei-1 & $14-17$ Mei 1999 \\
\hline Survei-2 & $12-14$ Februari 2001 \\
\hline Survei-3 & $26-27$ Juni 2002 \\
\hline
\end{tabular}

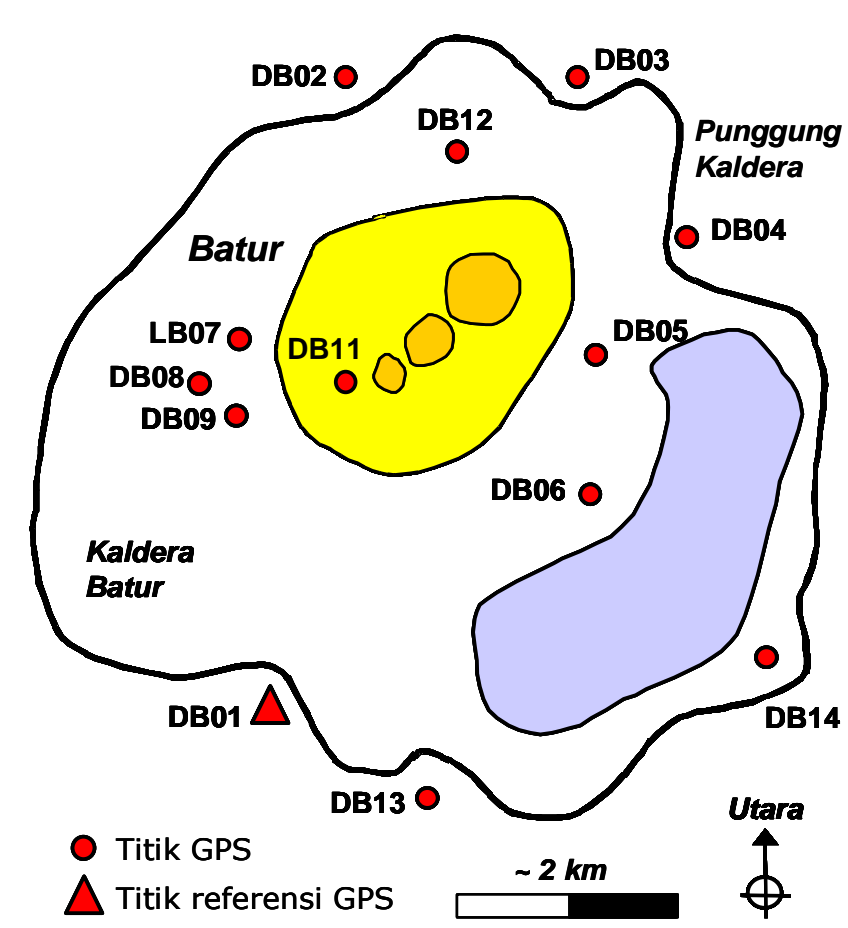

Gambar 2. Stasion-stasion pengamatan GPS di G. Batur (DB01 adalah titik referensi). 
Leica sistem 300. Pada survei yang ketiga digunakan tujuh receiver, yaitu dengan menggunakan tambahan dua receiver yaitu Leica sistem 500. Mengingat panjang baseline yang relatif pendek, lama sesi pengamatan GPS pada kedua survei GPS ini umumnya berkisar sekitar 10 jam.

\section{PENGOLAHAN DATA DAN HASIL}

Pengolahan data kedua survei GPS dilakukan dengan menggunakan perangkat lunak ilmiah BERNESSE 4.2 [8]. Pengolahan dilakukan secara radial dari titik DB01. Titik DB01 digunakan sebagai titik referensi untuk perhitungan, dan koordinatnya ditentukan dari titik BAKOSURTANAL di Cibinong yang merupakan titik geodetik orde-0 dari Jaring Kerangka Geodetik Nasional. Untuk seluruh perhitungan digunakan orbit satelit yang teliti (precise ephemeris), dan residu dari bias troposfir dan ionosfir di estimasi dalam proses perhitungan. Semua ambiguitas fase dapat ditentukan dengan baik, dan solusi akhir koordinat ditentukan dengan menggunakan data fase narrow-lane [1].

\subsection{Koordinat Titik Jaring GPS}

Koordinat geodetik (Lintang, Bujur, Tinggi Ellipsoid) titik-titik dalam jaring GPS berikut simpangan bakunya, yang diperoleh dari proses pengolahan data ketiga survei GPS yang telah dilaksanakan di G. Batur, diberikan pada Tabel 3. Berdasarkan nilai simpangan baku setiap komponen koordinat yang berada pada level beberapa $\mathrm{mm}$, dapat dikatakan bahwa pengolahan data GPS telah dilaksanakan dengan baik.

Tabel 3. Koordinat titik-titik jaring GPS untuk studi deformasi G. Batur.

\begin{tabular}{|c|c|c|c|c|c|c|}
\hline \multicolumn{7}{|c|}{ KOORDINAT TITIK DARI SURVEI GPS - 1} \\
\hline Titik & Lintang (S) & $\sigma_{L}(\mathrm{~mm})$ & Bujur (T) & $\sigma_{\text {B }}(\mathbf{m m})$ & Tinggi, $\mathbf{h}(\mathrm{m})$ & $\sigma_{\mathrm{h}}(\mathbf{m m})$ \\
\hline DB01 & $8^{\circ} 16^{\prime} 50.32741^{\prime \prime}$ & 0.0000 & $115^{\circ} 21^{\prime} 41.39423^{\prime \prime}$ & 0.0000 & 1403.0365 & 0.0000 \\
\hline DB02 & $8^{\circ} 13^{\prime} 05.26917^{\prime \prime}$ & 0.0008 & $115^{\circ} 21^{\prime} 20.93048^{\prime \prime}$ & 0.0008 & 1410.3259 & 0.0026 \\
\hline DB03 & $8^{\circ} 12^{\prime} 39.64399^{\prime \prime}$ & 0.0007 & $115^{\circ} 22^{\prime} 33.00280^{\prime \prime}$ & 0.0007 & 1324.6495 & 0.0021 \\
\hline DB04 & $8^{\circ} 13^{\prime} 23.97931^{\prime \prime}$ & 0.0007 & $115^{\circ} 24^{\prime} 05.66952 "$ & 0.0007 & 1333.6527 & 0.0020 \\
\hline DB06 & $8^{\circ} 15^{\prime} 12.37990^{\prime \prime}$ & 0.0005 & $115^{\circ} 23^{\prime} 50.48251^{\prime \prime}$ & 0.0005 & 1090.1741 & 0.0014 \\
\hline DB08 & \multicolumn{6}{|c|}{ belum ada titik } \\
\hline DB09 & $8^{\circ} 14^{\prime} 53.36342^{\prime \prime}$ & 0.0008 & $115^{\circ} 21^{\prime} 08.30652^{\prime \prime}$ & 0.0009 & 1126.5123 & 0.0025 \\
\hline DB11 & $8^{\circ} 14^{\prime} 47.19773^{\prime \prime}$ & 0.0014 & $115^{\circ} 22^{\prime} 00.89505^{\prime \prime}$ & 0.0015 & 1379.0668 & 0.0043 \\
\hline DB12 & $8^{\circ} 13^{\prime} 02.33356 "$ & 0.0007 & $115^{\circ} 22^{\prime} 01.12871^{\prime \prime}$ & 0.0007 & 1136.7627 & 0.0021 \\
\hline DB14 & $8^{\circ} 16^{\prime} 05.94959^{\prime \prime}$ & 0.0010 & $115^{\circ} 25^{\prime} 08.37349^{\prime \prime}$ & 0.0013 & 1086.8178 & 0.0023 \\
\hline \multicolumn{7}{|c|}{ KOORDINAT TITIK DARI SURVEI GPS - 2} \\
\hline DB01 & $8^{\circ} 16^{\prime} 50.32741^{\prime \prime}$ & 0.0000 & $115^{\circ} 21^{\prime} 41.39423^{\prime \prime}$ & 0.0000 & 1403.0365 & 0.0000 \\
\hline DB02 & $8^{\circ} 13^{\prime} 05.27047^{\prime \prime}$ & 0.0013 & $115^{\circ} 21^{\prime} 20.92748^{\prime \prime}$ & 0.0021 & 1410.4097 & 0.0053 \\
\hline DB03 & $8^{\circ} 12^{\prime} 39.64394 "$ & 0.0011 & $115^{\circ} 22^{\prime} 33.00253^{\prime \prime}$ & 0.0011 & 1324.6767 & 0.0031 \\
\hline DB04 & $8^{\circ} 13^{\prime} 23.97994^{\prime \prime}$ & 0.0012 & $115^{\circ} 24^{\prime} 05.66933^{\prime \prime}$ & 0.0014 & 1333.5835 & 0.0039 \\
\hline DB06 & $8^{\circ} 15^{\prime} 12.37979 "$ & 0.0010 & $115^{\circ} 23^{\prime} 50.48284^{\prime \prime}$ & 0.0012 & 1090.1322 & 0.0029 \\
\hline DB08 & $8^{\circ} 14^{\prime} 50.85590^{\prime \prime}$ & 0.0013 & $115^{\circ} 21^{\prime} 02.64708^{\prime \prime}$ & 0.0012 & 1120.8002 & 0.0035 \\
\hline DB09 & $8^{\circ} 14^{\prime} 53.36411^{\prime \prime}$ & 0.0012 & $115^{\circ} 21^{\prime} 08.30482 "$ & 0.0012 & 1126.4441 & 0.0034 \\
\hline DB11 & $8^{\circ} 14^{\prime} 47.19921^{\prime \prime}$ & 0.0010 & $115^{\circ} 22^{\prime} 00.89563^{\prime \prime}$ & 0.0011 & 1379.0102 & 0.0030 \\
\hline DB12 & $8^{\circ} 13^{\prime} 02.33405^{\prime \prime}$ & 0.0011 & $115^{\circ} 22^{\prime} 01.12818^{\prime \prime}$ & 0.0012 & 1136.8023 & 0.0034 \\
\hline DB14 & $8^{\circ} 16^{\prime} 05.95005^{\prime \prime}$ & 0.0009 & $115^{\circ} 25^{\prime} 08.37360^{\prime \prime}$ & 0.0013 & 1086.7924 & 0.0027 \\
\hline \multicolumn{7}{|c|}{ KOORDINAT TITIK DARI SURVEI GPS - 3} \\
\hline DB01 & $8^{\circ} 16^{\prime} 50.32741^{\prime \prime}$ & 0.0000 & $115^{\circ} 21^{\prime} 41.39423^{\prime \prime}$ & 0.0000 & 1403.0365 & 0.0000 \\
\hline DB02 & $8^{\circ} 13^{\prime} 05.26933^{\prime \prime}$ & 0.0012 & $115^{\circ} 21^{\prime} 20.93027^{\prime \prime}$ & 0.0013 & 1410.2793 & 0.0036 \\
\hline DB03 & $8^{\circ} 12^{\prime} 39.64482 "$ & 0.0009 & $115^{\circ} 22^{\prime} 33.00226^{\prime \prime}$ & 0.0011 & 1324.5988 & 0.0023 \\
\hline DB04 & $8^{\circ} 13^{\prime} 23.97993 "$ & 0.0010 & $115^{\circ} 24^{\prime} 05.66916^{\prime \prime}$ & 0.0011 & 1333.6418 & 0.0025 \\
\hline DB06 & $8^{\circ} 15^{\prime} 12.38000^{\prime \prime}$ & 0.0006 & $115^{\circ} 23^{\prime} 50.48279^{\prime \prime}$ & 0.0006 & 1090.1972 & 0.0015 \\
\hline DB08 & $8^{\circ} 14^{\prime} 50.85565^{\prime \prime}$ & 0.0010 & $115^{\circ} 21^{\prime} 02.64796 "$ & 0.0007 & 1120.7419 & 0.0021 \\
\hline DB09 & $8^{\circ} 14^{\prime} 53.36449^{\prime \prime}$ & 0.0012 & $115^{\circ} 21^{\prime} 08.30518^{\prime \prime}$ & 0.0008 & 1126.4523 & 0.0024 \\
\hline DB11 & $8^{\circ} 14^{\prime} 47.19878^{\prime \prime}$ & 0.0008 & $115^{\circ} 22^{\prime} 00.89599^{\prime \prime}$ & 0.0007 & 1379.0014 & 0.0020 \\
\hline DB12 & $8^{\circ} 13^{\prime} 02.33472 "$ & 0.0011 & $115^{\circ} 22^{\prime} 01.12784^{\prime \prime}$ & 0.0008 & 1136.8126 & 0.0024 \\
\hline DB14 & $8^{\circ} 16^{\prime} 05.94960^{\prime \prime}$ & 0.0010 & $115^{\circ} 25^{\prime} 08.37330^{\prime \prime}$ & 0.0015 & 1086.7828 & 0.0030 \\
\hline
\end{tabular}




\subsection{Perubahan Jarak Antar Titik}

Karena adanya fenomena deformasi, maka jarak antar titik akan berubah. Gambar 3 dan Gambar 4 berikut menunjukkan perubahan ja-rak datar antar beberapa titik pengamatan GPS. Da-lam hal ini karena titik DB11 terletak pada tubuh gunung Batur dan berada relatif dekat dengan kawah Batur ke-3 yang aktif, maka perubahan jarak dilihat terhadap beberapa baseline yang terikat dengan titik DB11 ini. Dalam hal ini jarak-jarak datar dihitung berdasarkan koordinat titik-titik GPS yang diperoleh dari proses pengolahan data survei GPS.

Dari Gambar 3 terlihat bahwa dalam periode Mei 1999 sampai Februari 2001 terjadi proses inflasi pada tubuh Batur bagian barat-daya yang berdekatan dengan kawah aktif, yang ditunjukkan dengan pemendekan baseline DB11-DB09 dan DB11-DB01 serta pemanjangan baseline dari DB11 ke titik-titik DB02, DB03, DB04, DB06, DB12 dan DB14. Proses inflasi ini menunjukkan terjadinya peningkatan aktivitas G. Batur. Selama periode tersebut, yaitu sekitar dua tahun, terjadi perubahan jarak datar dalam orde 1-3 $\mathrm{cm}$.

Setelah terjadi proses inflasi, Gambar 4 menunjukkan terjadinya proses deflasi pada tubuh barat-daya dari Batur. Hal ini ditunjukkan dengan pemanjangan baseline dari DB11 ke titik-titik DB08, DB09 dan DB01, serta pemendekan baseline dari DB11 ke titik-titik DB02, DB03, DB04 dan DB12

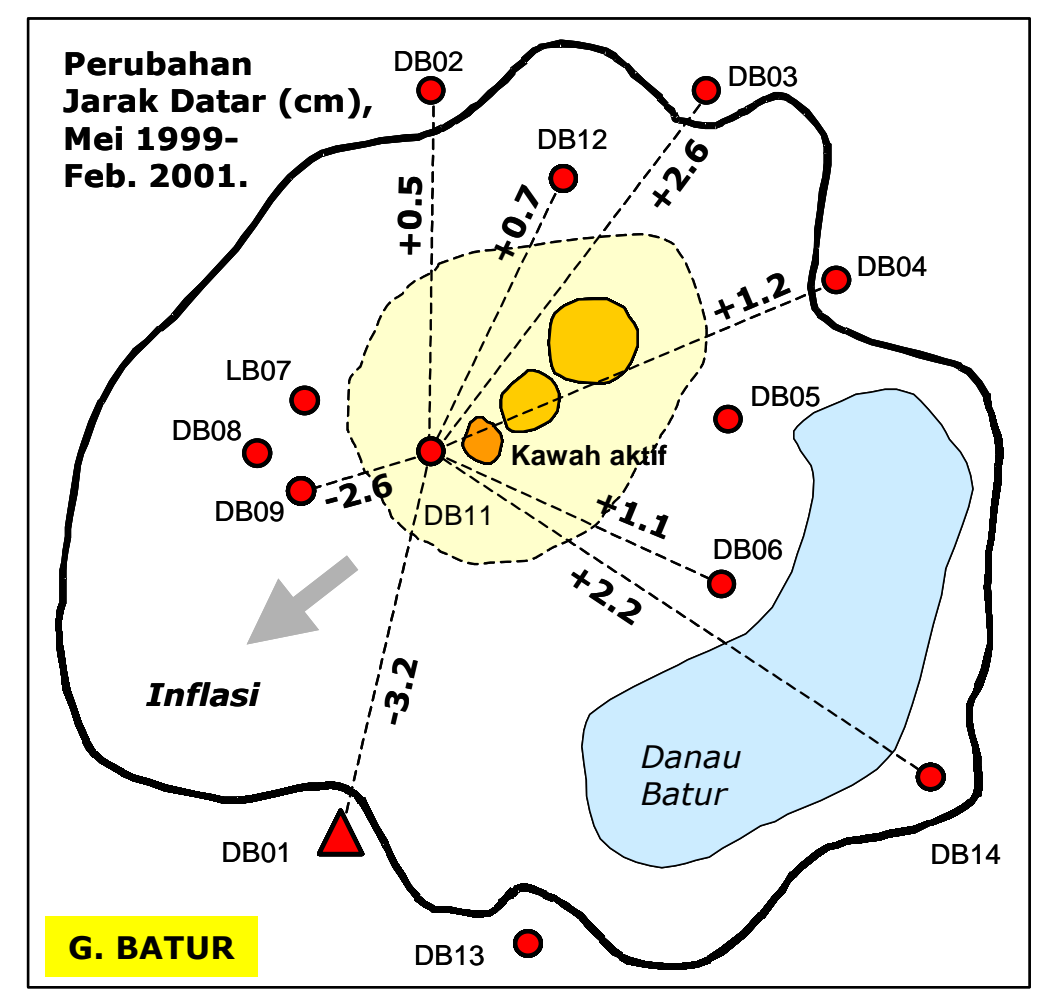

Gambar 3. Perubahan jarak datar antar titik GPS, dari survei 1 ke survei 2 (Mei 1999 - Februari 2001) 


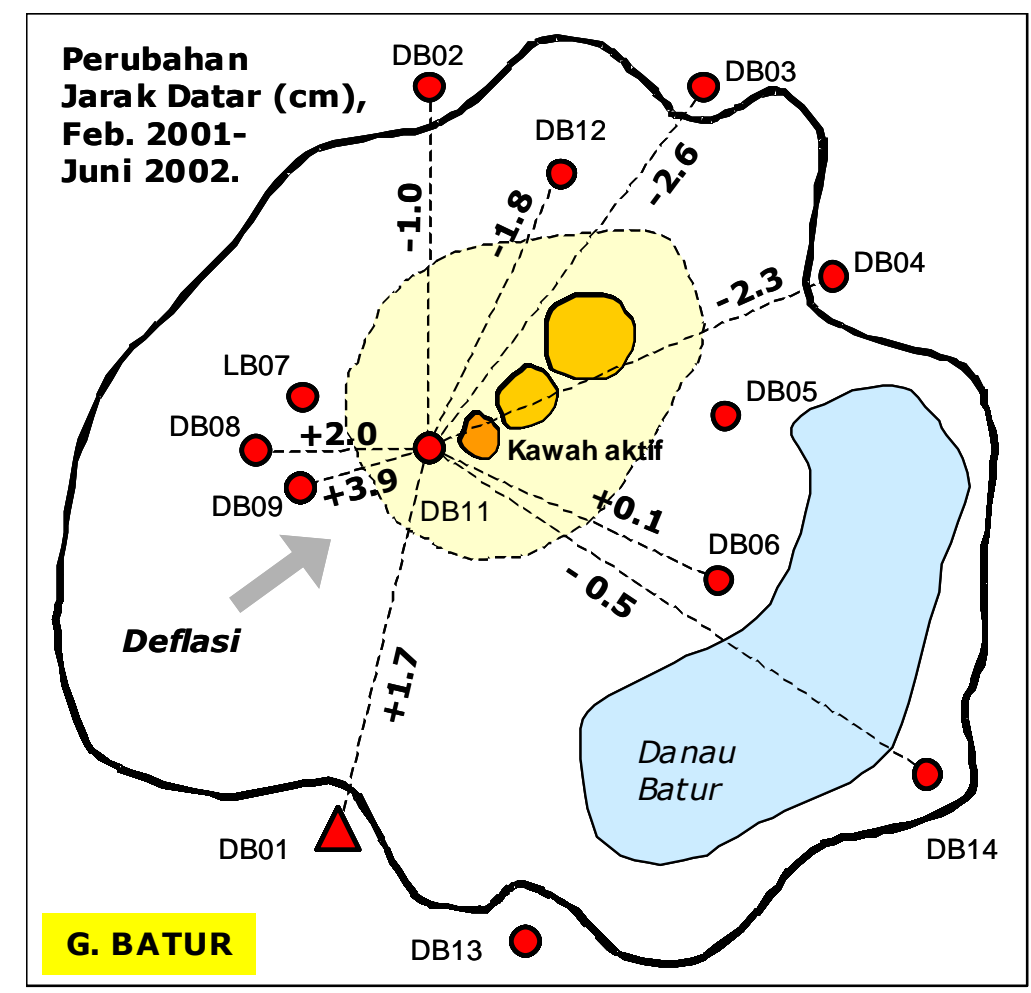

Gambar 4. Perubahan jarak datar antar titik GPS, dari survei 2 ke survei 3 (Februari 2001 - June 2002)

\subsection{Lokasi Pusat Tekanan}

Dalam konteks deformasi gunungapi, data vektor pergeseran titik-titik pada tubuh gununapi yang bersangkutan dapat digunakan untuk menentukan karakteristik (seperti lokasi) dari pusat tekanan penyebab terjadinya pergeseran posisi titik-titik tersebut. Dalam hal ini model Mogi [6], yang diilustrasikan pada Gambar 5, umum digunakan untuk menentukan lokasi dari pusat tekanan tersebut.

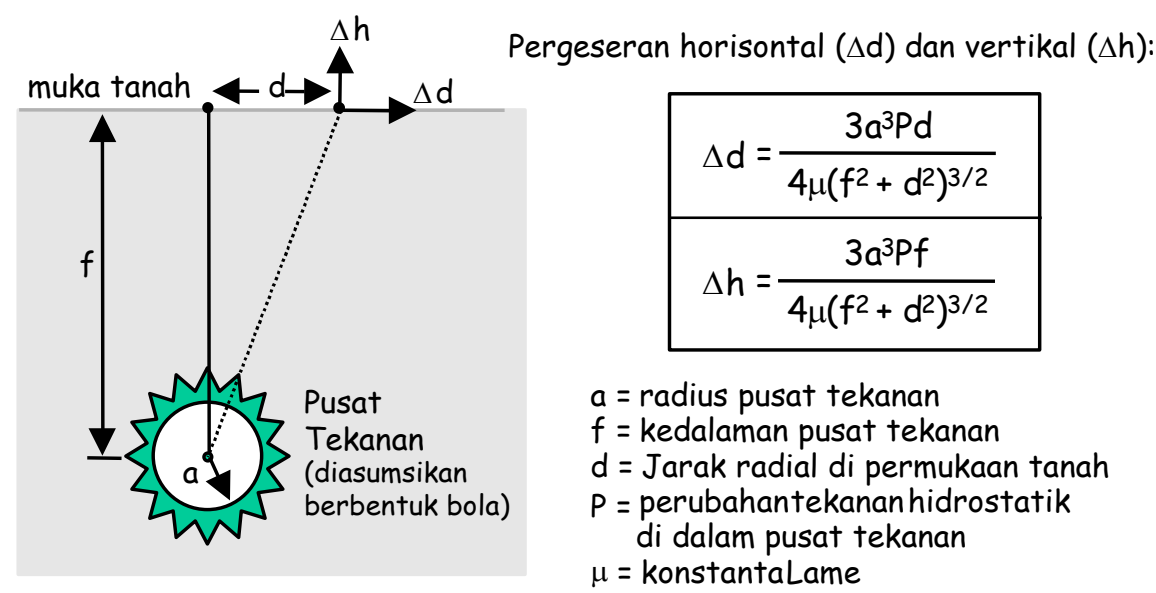

Gambar 5. Deskripsi dari Model Mogi [6].

Penentuan pusat tekanan dalam studi ini menggunakan pendekatan dari Nisihi [7] dalam implementasi model Mogi. Pada pendekatan Nishi ini, yang digunakan sebagai kriteria untuk pencarian lokasi posisi pusat tekanan yang paling sesuai dengan pola vektor pergeseran titik-titik adalah kesesuaian antara perubahan panjang baseline yang diamati dengan perubahan panjang baseline yang dihitung dengan model Mogi. 
Pada pendekatan Nishi, perubahan panjang baseline $\left(\square \mathrm{L}_{12}\right)$ antara titik-1 $\left(\mathrm{x}_{1}, \mathrm{y}_{1}\right)$ dengan titik-2 $\left(\mathrm{x}_{2}, \mathrm{y}_{2}\right)$ dihitung dengan formula berikut [7] :

$$
\Delta \mathrm{L}_{12}=\frac{\left(\mathrm{x}_{2}-\mathrm{x}_{1}\right) \cdot \mathrm{X}_{12}+\left(\mathrm{y}_{2}-\mathrm{y}_{1}\right) \cdot \mathrm{Y}_{12}}{\mathrm{R}_{1}^{3} \cdot \mathrm{R}_{2}^{3} \cdot \mathrm{L}_{12}} \cdot \mathrm{k}
$$

Pada persamaan (1) di atas :

$$
\begin{array}{ll}
\mathrm{R}_{\mathrm{i}}=\left\{\left(\mathrm{x}_{\mathrm{i}}-\mathrm{x}\right)^{2}+\left(\mathrm{y}_{\mathrm{i}}-\mathrm{y}\right)^{2}+\mathrm{z}^{2}\right\}^{1 / 2},(\mathrm{i}=1,2), & \mathrm{k}=3 \mathrm{a}^{3} \cdot \mathrm{p} /(4 \mu) \\
\mathrm{X}_{12}=\left(\mathrm{x}_{2}-\mathrm{x}\right) \cdot \mathrm{R}_{1}^{3}-\left(\mathrm{x}_{1}-\mathrm{x}\right) \cdot \mathrm{R}_{2}^{3}, & \mathrm{~L}_{12}=\text { panjang baseline antara titik } 1 \text { dan } 2 \\
\mathrm{Y}_{12}=\left(\mathrm{y}_{2}-\mathrm{y}\right) \cdot \mathrm{R}_{1}^{3}-\left(\mathrm{y}_{1}-\mathrm{y}\right) \cdot \mathrm{R}_{2}^{3}, & (\mathrm{x}, \mathrm{y}, \mathrm{z})=\text { koordinat dari lokasi pusat tekanan }
\end{array}
$$

Selanjutnya lokasi pusat tekanan dicari dengan meminimalkan fungsi berikut :

$$
\chi^{2}=\sum_{i=1}^{N}\left(\frac{\Delta \mathrm{L}_{\mathrm{i}}^{\mathrm{obs}}-\Delta \mathrm{L}_{\mathrm{i}}^{\mathrm{cal}}}{\sigma_{\mathrm{i}}}\right)
$$

dimana $\Delta \mathrm{L} 12^{\text {obs }}$ dan $\Delta \mathrm{L} 12^{\text {calc }}$ adalah perubahan panjang baseline yang diamati dan dihitung, dan $\square_{i}$ adalah deviasi standar dari perubahan panjang baseline yang diamati.

Dengan mengasumsikan bahwa vektor pergeseran yang diperoleh dari survei GPS merepresentasikan deformasi aktual yang dialami oleh gunung Batur, maka model Mogi dapat digunakan untuk mengestimasi lokasi dari pusat tekanan penyebab deformasi tersebut. Pengolahan data dilakukan dengan menggunakan program yang ditulis dengan perangkat lunak MATLAB. Hasil yang diperoleh ditunjukkan pada Tabel 4 dan Gambar 6 berikut.

Dari Tabel 4 dan Gambar 6 terlihat bahwa pusat tekanan yang

\begin{tabular}{|c|c|}
\hline \multicolumn{2}{|c|}{$\begin{array}{l}\text { Hasil estimasi pusat tekanan } \\
\text { G. Batur berdasarkan Model Mogi }\end{array}$} \\
\hline Easting & 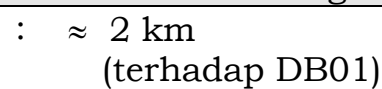 \\
\hline Northing & $: \approx 4 \mathrm{~km}$ \\
\hline Kedalaman & $\begin{array}{c}: \approx \mathrm{km} \text { di bawah } \\
\text { dasar kaldera }\end{array}$ \\
\hline Nilai k & $: \approx 10^{5}$ \\
\hline
\end{tabular}
menyebabkan terjadinya deformasi G. Batur yang diamati oleh tiga survei GPS tersebut kira-kira berada di bawah kawah Batur yang kedua, dengan kedalaman sekitar $2 \mathrm{~km}$ dari dasar kaldera.

Tabel 4. Parameter pusat tekanan

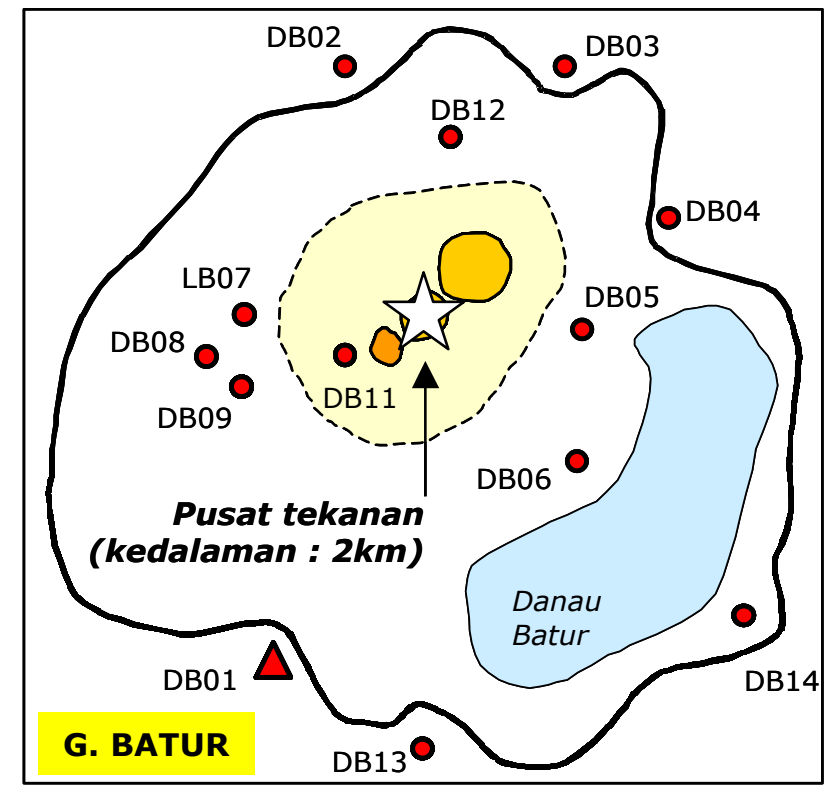

Gambar 6. Lokasi pusat tekanan G. Batur

Kalau kita melihat kedudukan ketiga kawah gunung Batur yang berjajar dalam arah timur-laut ke barat-daya, dari mulai yang tua sampai yang termuda, maka lokasi sumber tekanan ini adalah sesuai dengan perkiraan. Hanya dalam hal ini kedalamannya yang perlu diverifikasi dari data pengamatan seismik. 
Kalau kita bandingkan dengan pola pemanjangan dan pemendekan panjang baseline yang telah ditunjukkan pada Gambar 3 dan 4 sebelumnya, maka dapat disimpulkan bahwa gaya tekan terhadap tubuh gunung dari pusat tekanan berarah miring, yaitu ke arah barat-daya dari pusat tekanan. Oleh sebab itu untuk selanjutnya, kawasan baratdaya dari kawah Batur ketiga ini perlu mendapatkan perhatian yang lebih dalam konteks studi deformasi G. Batur karena kemungkinan besar bagian inilah yang akan mempunyai dinamika deformasi yang relatif tinggi.

\section{CATATAN PENUTUP}

Metode survei GPS mempunyai kemampuan untuk mempelajari deformasi gunungapi dengan ketelitian relatif (vektor pergeseran titik) yang cukup tinggi, yaitu sampai level presisi samapai beberapa $\mathrm{mm}$. Meskipun begitu, pencapaian tingkat ketelitian yang tinggi ini bukanlan suatu hal yang mudah. Untuk mencapai tingkat kepresisian $\mathrm{mm}$ tersebut diperlukan penggunaan receiver GPS tipe geodetik dua-frekuensi, perencanaan survei yang cermat, strategi pengamatan yang ketat, serta strategi pengolahan data yang baik dengan memanfaatkan perangkat lunak ilmiah untuk pengolahan datanya. Dengan kemampuannya untuk memantau sinyal deformasi pada tingkat ketelitian yang cukup tinggi tersebut, maka studi deformasi gunung Batur dengan menggunakan metode survei GPS ini akan terus dilanjutkan, disamping juga studi deformasi gununggunungapi lainnya yang juga tengah dilakukan oleh tim peneliti, yaitu gunung-gunung Guntur, Papandayan, Galunggung, Kelut, Bromo dan Ijen.

Dalam konteks kegiatan studi deformasi gunung Batur ini, disamping melanjutkan pelaksanaan metode survei GPS, korelasi yang lebih komprehensif antara karakteristik deformasi yang diperoleh dari GPS dengan karakteristik geologis, magmatis, dan hidrologis dari gunung Batur dan kawasan sekitarnya, juga akan ditelaah. Disamping itu pemanfaatan metode INSAR (Interferometric Synthetic Aperture Radar) untuk mendapatkan medan deformasi kaldera Batur yang secara spasial lebih menyeluruh juga tengah dipersiapkan.

\section{UCAPAN TERIMA KASIH}

Penelitian ini dapat terlaksana berkat adanya kerjasama dan dukungan dari Direktorat Vulkanologi dan Mitigasi Bencana Geologi (DVMBG) dengan Departemen Teknik Geodesi ITB. Dalam hal ini kami ucapkan banyak terima kasih pada Dr. Achmad D. Wirakusumah dan Ir. Samsul Rizal dari DVMBG, untuk dukungan administratif, transportasi dan akomodasi sekaligus dukungan moralnya bagi kerjasama ini. Ucapan terima kasih yang khusus juga perlu kami sampaikan pada para mahasiswa Teknik Geodesi ITB, staf DVMBG serta pengamat gunung Batur dan Agung, yaitu Agung, Nengah dan Komang yang telah banyak membantu tim peneliti dalam suksesnya pelaksanaan survei GPS di kawasan gunung Batur. 


\section{DAFTAR ACUAN}

1. Abidin, H.Z. (2000). Penentuan Posisi Dengan GPS dan Aplikasinya. P.T. Pradnya Paramita, Jakarta. Edisi ke 2. ISBN 979-408-377-1. 268 pp.

2. Situs internet dari Direktorat Vulkanologi dan Mitigasi Bencana Geologi, alamat situs : http://www.vsi.dpe.go.id/volcanoes/batur.html, 14 September 2002.

3. Direktorat Vulkanologi (1990). Gunung Batur. Berita Berkala Vulkanologi, Edisi Khusus, No. 158, 9 pp.

4. McGuire, W.J. (1995). "Monitoring active volcanoes - an introduction", In Monitoring Active Volcanoes by B. McGuire, C.R.J. Kilburn, and J. Murray (Eds), pp. 1-31, UCL Press Limited, London, $421 \mathrm{pp}$.

5. McGuire B., C.R.J. Kilburn, and J. Murray (Eds) (1995) Monitoring Active Volcanoes, UCL Press Limited, London, $421 \mathrm{pp}$.

6. Mogi, K. (1958). Relation between the eruption of various volcanoes and the deformation of the ground surface around them. Bulletin of Earthquake Research Institute, Vol. 36, pp. 99-134.

7. Nishi,K., H. Ono, H. Mori (1999). Global Positioning System measurements of ground deformation caused by magma intrusion and lava discharge: the 1990-1995 eruption at Unzendake volcano, Kyushu, Japan. Journal of Volcanology and Geothermal Research, Volume 89, Nos. 1-4, pp. 23-34.

8. Rothacher. M. and L. Mervart (Eds.) (1996). Bernesse GPS Software version 4.0. Astronomical Institute. University of Berne. September. 418 pp.

9. Scarpa, R. and R.I. Tilling (Eds.) (1996). Monitoring and Mitigation of Volcano Hazards. Springer Verlag, Berlin, 841 pp.

10. Van der Laat, R. (1996) "Ground-Deformation Methods and Results." In Monitoring and Mitigation of Volcano Hazards by R. Scarpa and R.I. Tilling (Eds.), Springer Verlag, Berlin, pp. 147 - 168.

11. Van Bemmelen ,R.W. (1949). The Geology of Indonesia, Government Printing Office, The Hague.

12. Situs internet dari Geopoint, alamat : http://www.geopoint.com.au/ profilevendor . asp? P1=Batur_Volcano\&P3=1\&P5=np, 14 September 2002. 